\title{
A semi-quantitative survey of macroinvertebrates at selected sites to evaluate the ecosystem health of the Olifants River
}

\author{
CT Wolmarans ${ }^{1 *}, M_{\text {Kemp }}^{1}$, KN de Kock'1, W Roets ${ }^{2}$, L van Rensburg' and L Quinn ${ }^{3}$ \\ 'Unit for Environmental Sciences and Management, North-West University, Potchefstroom Campus, Private Bag X6001, \\ Potchefstroom 2520, South Africa \\ ${ }^{2}$ Department of Water Affairs, Western Cape Province, South Africa \\ ${ }^{3}$ National Metrology Institute of South Africa, Pretoria, South Africa
}

\begin{abstract}
This study was conducted to evaluate the ecosystem health of the Olifants River by means of semi-quantitative surveys of the macroinvertebrates at 7 selected sites in the catchment. These surveys were performed during the high- and low-flow seasons for 2 consecutive years. Macroinvertebrates were collected by using a net consisting of a $30 \mathrm{~cm}$ square steel frame with a sturdy handle, to which a Perlon gauze net with a mesh of $1 \mathrm{~mm}$ was attached. Semi-quantitative surveys were done by sampling the vegetation, as well as the substratum, with the net at each site for approximately $15 \mathrm{~min}$. The $\mathrm{pH}$, water temperature and conductivity were measured in situ at each site during the different surveys. Samples were fixed and preserved in $90 \%$ ethanol and thereafter sorted, identified up to family level and counted. The specimens were categorised as tolerant, moderately sensitive or highly sensitive, according to the guidelines set by the South African Scoring System Version 5 (SASS5). Although a total of 95 taxa were recovered during this study, only 7 of these taxa were categorised as highly sensitive, it can be concluded that the water of the Olifants River is in a poor state of health as revealed by the macroinvertebrate assemblages.
\end{abstract}

Keywords: Olifants River, macroinvertebrates, river health

\section{INTRODUCTION}

The Olifants River Catchment is subjected to extreme demand for natural resources and associated land modification and pollution (Ballance et al., 2001). Van Vuuren (2009) quotes the view of aquatic ecologist Dr Peter Ashton that, next to the Vaal River, the Olifants River is probably the hardest working river in South Africa, having been used and abused for over 5 decades, and that pollution is progressively worsening. Rashleigh et al. (2009) also concluded that the water quality of the Olifants River is not in a desirable state. Although this river is often described as one of the most polluted rivers in Southern Africa (Batchelor, 1992; Engelbrecht, 1992; De Villiers and Mkwelo, 2009; Heath et al., 2010; CSIR, 2012) the quality of ecological units varies from moderate to poor (Ballance et al., 2001). Ecological systems which were deemed to be moderately impacted in a 2001 study include the Tongwane, upper reaches of the Mohlapitse and the major part of the Blyde River, where natural conditions are maintained, as well as the lower reaches which are protected by conservation activities (Ballance et al., 2001). In the upper part of the Olifants catchment mining activities are one of the main contributors to the negative impacts on river health (Ballance et al., 2001; O'Keeffe and Le Quesne, 2009). This area is characterised by extensive invasion of alien vegetation and to a lesser extent alien fauna (Ballance et al., 2001). The releases of water and sediment from impoundments without sufficient regard for ecological impacts are the major causes of downstream environmental degradation (Ballance et al., 2001). These phenomena are

\footnotetext{
To whom all correspondence should be addressed.

욜 +27 18299 2389; fax: +27 18299 2370;

e-mail: corrie.wolmarans@nwu.ac.za

Received 4 September 2012; accepted in revised form 4 March 2014.
}

especially relevant with regard to the middle and lower parts of the Olifants River catchment (Ballance et al., 2001). Our own observations during surveys in 1995 (De Kock and Wolmarans, 1998), 2001 (De Kock et al., 2002) and 2006 (Wolmarans and De Kock, 2006) to investigate the diversity of freshwater molluscs in water bodies, including the Olifants River, in the Kruger National Park (KNP), also pointed to a decrease in species diversity and number of specimens per species.

The controversy around the health of this river most likely results from a lack of detailed data pertaining to the macroinvertebrate diversity of this river. Macroinvertebrates are well known to have different sensitivities to pollution and habitat transformation and are therefore very useful indicators of pollution. Different taxa of macroinvertebrates also exhibit differing tolerances to individual water quality variables (Dallas and Day, 1993), therefore water of suitable quality is essential to maintain healthy populations of aquatic organisms (Malan and Day, 2003). For the classification of sensitivity the SASS5 sensitivity scores for individual taxa can be used (Dickens and Graham, 2002). Due to the fact that macroinvertebrate assemblages are often used to determine biotic integrity or ecological health of river ecosystems (Oberholster et al., 2005; Masese et al., 2009; Malherbe et al., 2010; Arimoro et al., 2011), it was decided to do a semi-quantitative survey to provide an indication of water quality and ecosystem health at various preselected sampling sites in the river, spread over several of its tributaries.

\section{MATERIALS AND METHODS}

\section{Sampling equipment and techniques}

Two surveys of aquatic macroinvertebrates were conducted during both high and low flow periods for 2 successive years at 7 preselected sites. 
According to Phiri et al. (2012), macroinvertebrates may reside on or within sediments, or may be associated with aquatic vegetation. Therefore, semi-quantitative surveys were done by sampling the vegetation, as well as the substratum, with a net $(30 \mathrm{~cm}$ square steel frame with a sturdy handle and a Perlon gauze net with a mesh size of $1 \mathrm{~mm}$ ) at each selected site for approximately $15 \mathrm{~min}$. Marginal and aquatic vegetation were sampled by pushing the net vigorously into the vegetation and moving it backwards and forwards through the same area (Dickens and Graham, 2002). Macroinvertebrates on substrata of biotopes consisting mainly of mud, sand, gravel or stones were collected by shuffling the feet whilst continuously sweeping the net over the disturbed area (Dickens and Graham, 2002). Contents of the net were then transferred to a rectangular plastic container $(360 \times 470 \times 80 \mathrm{~mm})$ which was filled with filtered water from the habitat to a level of approximately $40 \mathrm{~mm}$. Most of the debris/coarse material were then carefully removed by hand. Thereafter the contents of the container were decanted into a cone-shaped Perlon gauze net $(0.25 \mathrm{~mm}$ mesh) suspended on a stand. The contents of the net were transferred to a plastic container with a tight-fitting lid and $90 \%$ ethanol was added to preserve the samples. The container was then labelled with relevant site information. Collections made in the marginal and aquatic vegetation were dealt with in a similar way.

The samples were transported to the laboratory where each sample was decanted into a rectangular Perspex sorting tray $(300 \times 200 \times 25 \mathrm{~mm})$ with a transparent bottom provided with a $10 \mathrm{~mm}$ square grid. All macroinvertebrates were removed by using a stereomicroscope mounted on a sliding stand. Additionally identification was done under a stereo microscope, with the aid of the Guide to the Freshwater Invertebrates Of Southern Africa series published by the Water Research Commission (Seaman et al., 1999; Hamer, 1999; Griffiths and Stewart 2001; Hart et al., 2001; Kensley, 2001; Martens, 2001; Rayner, 2001; Van As and Van As 2001; Appleton, 2002a; Appleton, 2002b; Dippenaar-Schoeman, 2002; Jansen van Rensburg and Day, 2002; Oosthuizen and Siddall, 2002; Rayner et al., 2002; Van Hoven and Day, 2002; Barber-James and LugoOritiz, 2003; Coetzee, 2003; de Meillon and Wirth, 2003; de Moor, 2003; De Moor and Scott, 2003; Harrison 2003; Harrison et al, 2003a; Harrison et al, 2003b Henning, 2003; Mansell, 2003; Reavell, 2003; Samways and Wilmot 2003; Biström, 2007; Endrödy-Younga, 2007a; Endrödy-Younga, 2007b; EndrödyYounga and Stals, 2007a; Endrödy-Younga and Stals, 2007b; Endrödy-Younga and Stals, 2007c; Endrödy-Younga and Stals 2007d; Grobbelaar, 2007; Nelson, 2007a; Nelson, 2007b; Perkins, 2007; Shepard and Lee, 2007; Stals, 2007a; Stals, 2007b Stals and Endrödy-Younga, 2007), as well as additional literature (Davies and Day, 1998; Gerber and Gabriel, 2002a; Gerber and Gabriel, 2002b). Where possible, organisms were identified up to the genus level, otherwise identification was done up to the family level. Subsequently all specimens were counted and classified. The SASS 5 scores (Dickens and Graham, 2002) were used for this study to classify the macroinvertebrates collected into 3 groups, namely tolerant (scores 1-5), moderately sensitive (scores 6-10) and highly sensitive to pollution (scores 11-15). Where families collected during this study were not included in the SASS 5 ratings, no scores were allocated.

The coordinates and altitude of each sampling site were determined with a Garmin Nuvi 500 GPS and from Google Earth. The species of dominant marginal and aquatic vegetation were identified with the aid of a guide (Gerber et al., 2004) and recorded for each of the sampling sites.

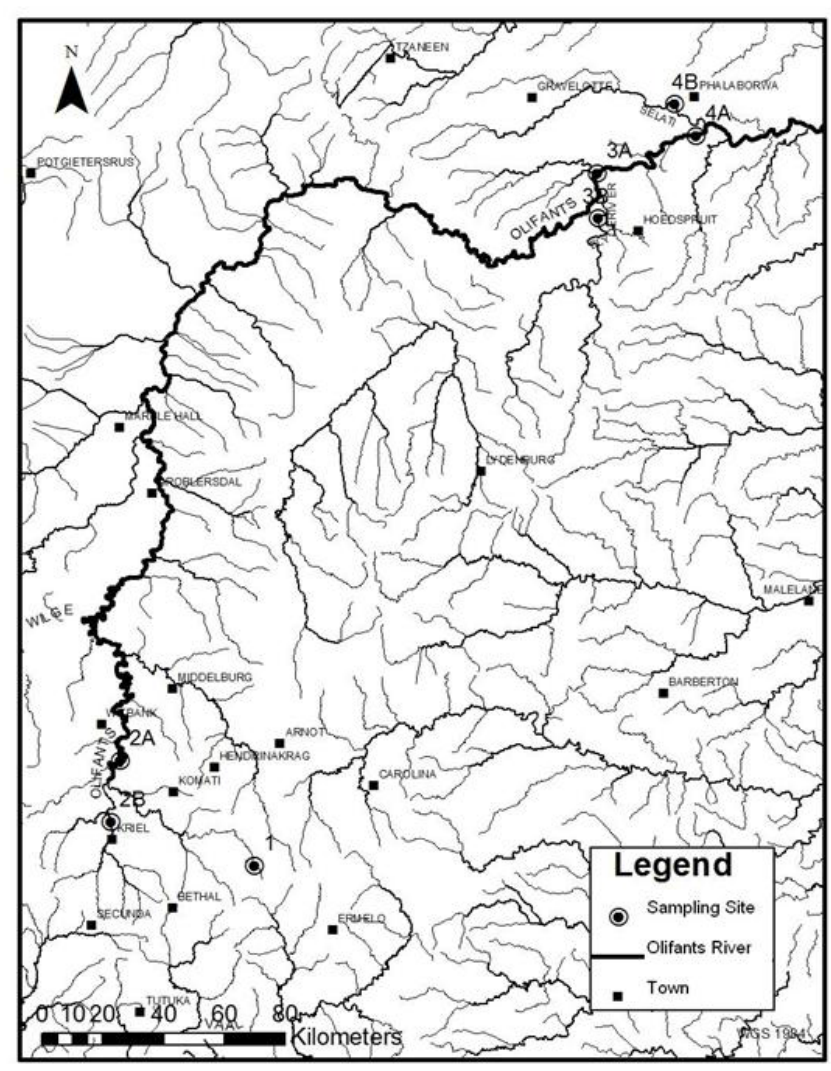

Figure 1

Map of the study area

\section{Statistical analyses}

To further analyse the community structure within the Olifants River Catchment, a combination of biological indices (species richness, Shannon-Wiener diversity index and Pielou's evenness index, \% Oligochaeta, \% Chironomidae, Spearman rank order correlation and exploratory statistical analyses (principle component analysis (PCA)) were conducted. Biological indices are used as a tangible indicator of the ecological attributes of a specific ecological unit by describing the biodiversity within that unit. Indices most commonly used include species richness, the Shannon-Wiener diversity index and Pielou's evenness index (Begon et al., 1996; Türkmen and Kazanci 2010). All statistical analyses were done with the aid of Statistica (Version 10) and Canoco (Version 4).

\section{The study area}

The 7 sites selected for the investigation are depicted in Fig. 1.

\section{RESULTS}

During this study, a total of 95 taxa were collected at the various sampling sites. Eighty three (83)of these taxa were each represented by less than $1 \%$ of the total number of specimens sampled, while the remaining 12 taxa were each represented by more than $1 \%$ of the total number of specimens collected (Table 2). Of the 12 families collected in numbers higher than $1 \%, 11$ were found at Sites 1,2A and 2B and 10 of these families were collected at Sites 3B and 4A (Table 3). The Thiaridae were dominant during the study, followed by Tubificidae, Baetidae and Corixidae. Of the Thiaridae, 2 species were collected, 


\begin{tabular}{|c|c|c|c|c|c|c|}
\hline \multicolumn{7}{|c|}{$\begin{array}{c}\text { TABLE } 1 \\
\text { Habitat description and sampling sites. }\end{array}$} \\
\hline $\begin{array}{l}\text { Sampling } \\
\text { sites }\end{array}$ & Area & $\begin{array}{l}\text { Localities and } \\
\text { river zones }\end{array}$ & Coordinates & \begin{tabular}{|l|} 
Height \\
above sea \\
level $(\mathrm{m})$ \\
\end{tabular} & Habitat description & Dominant vegetation \\
\hline Site 1 & $\begin{array}{l}\text { Ermelo } \\
\text { district }\end{array}$ & $\begin{array}{l}\text { Olifants River } \\
\text { near source. } \\
\text { Upper foothill } \\
\text { zone }\end{array}$ & $\begin{array}{l}26^{\circ} 19^{\prime} 46.4^{\prime \prime} \mathrm{S} \\
29^{\circ} 43^{\prime} 38.9^{\prime \prime} \mathrm{E}\end{array}$ & 1667 & $\begin{array}{l}\text { Intermediate } \\
\text { zone, moderate flow over sand- } \\
\text { gravel substrates. } \\
\text { Weir, water clear, shallow to deep, } \\
\text { slow to fast-running, sandy, stony } \\
\text { and muddy substratum. } \\
\end{array}$ & $\begin{array}{l}\text { Phragmites australis, } \\
\text { Typha capensis, Berula } \\
\text { erecta and Marsilea sp. }\end{array}$ \\
\hline Site $2 \mathrm{~A}$ & $\begin{array}{l}\text { Witbank } \\
\text { district }\end{array}$ & $\begin{array}{l}\text { Olifants } \\
\text { River. Lower } \\
\text { foothill zone } \\
\text { with numer- } \\
\text { ous lowland } \\
\text { characteristics. } \\
\end{array}$ & $\begin{array}{l}26^{\circ} 00^{\prime} 00.0^{\prime \prime} \mathrm{S} \\
29^{\circ} 17^{\prime} 50.3^{\prime \prime} \mathrm{E}\end{array}$ & 1515 & $\begin{array}{l}\text { Depositional } \\
\text { zone, slack } \\
\text { water, deposition of finer sediment } \\
\text { particles. } \\
\text { Muddy to sandy substratum. } \\
\text { Backup of the Witbank Dam. } \\
\end{array}$ & $\begin{array}{l}\text { Typha capensis, Juncus } \\
\text { lomatophyllus, Cyperus } \\
\text { sp. and Ceratophyllum } \\
\text { demersum }\end{array}$ \\
\hline Site 2B & $\begin{array}{l}\text { Bethal } \\
\text { district }\end{array}$ & $\begin{array}{l}\text { Steenkool } \\
\text { Spruit. } \\
\text { Lowland zone } \\
\text { with numer- } \\
\text { ous lowland } \\
\text { characteristics. }\end{array}$ & $\begin{array}{l}26^{\circ} 11^{\prime} 33.7^{\prime \prime} \mathrm{S} \\
29^{\circ} 15^{\prime} 55.8^{\prime \prime} \mathrm{E}\end{array}$ & 1534 & $\begin{array}{l}\text { Intermediate zone, moderate flow } \\
\text { over sand-gravel. } \\
\text { Water clear, fast-running, substra- } \\
\text { tum mainly bedrock, little mud and } \\
\text { sand. }\end{array}$ & $\begin{array}{l}\text { Phragmites australis, } \\
\text { Cyperus sexangularis, } \\
\text { Veronica anagallis- } \\
\text { aquatica and Persicaria } \\
\text { lapathifolia }\end{array}$ \\
\hline Site $3 \mathrm{~A}$ & $\begin{array}{l}\text { Letaba } \\
\text { district }\end{array}$ & $\begin{array}{l}\text { Olifants River } \\
\text { near Mica. } \\
\text { Foothill zone. }\end{array}$ & $\begin{array}{l}24^{\circ} 11^{\prime} 14.3^{\prime \prime} \mathrm{S} \\
30^{\circ} 49^{\prime} 31.1^{\prime \prime} \mathrm{E}\end{array}$ & 372 & $\begin{array}{l}\text { Erosional zone } \\
\text { Water clear, shallow, slow-running, } \\
\text { sandy substratum, signs of erosion. }\end{array}$ & Phragmites mauritianus \\
\hline Site 3B & \begin{tabular}{l|} 
Pilgrims \\
Rest \\
district
\end{tabular} & $\begin{array}{l}\text { Blyde River. } \\
\text { Foothill zone. }\end{array}$ & $\begin{array}{l}24^{\circ} 19^{\prime} 47.0^{\prime \prime} \mathrm{S} \\
30^{\circ} 49^{\prime} 50.6^{\prime \prime} \mathrm{E}\end{array}$ & 453 & $\begin{array}{l}\text { Erosional zone } \\
\text { Water clear, broad and shallow, } \\
\text { slow- to fast-running, muddy and } \\
\text { sandy substratum. }\end{array}$ & $\begin{array}{l}\text { Phragmites mauritianus, } \\
\text { Cyperus eragrostis and } \\
\text { Persicaria decipiens }\end{array}$ \\
\hline Site $4 \mathrm{~A}$ & $\begin{array}{l}\text { Letaba } \\
\text { district }\end{array}$ & $\begin{array}{l}\text { Olifants } \\
\text { River south of } \\
\text { Phalaborwa. } \\
\text { Lower foothill } \\
\text { zone. }\end{array}$ & $\begin{array}{l}24^{\circ} 04^{\prime} 23.1^{\prime \prime} \mathrm{S} \\
31^{\circ} 08^{\prime} 28.8^{\prime \prime} \mathrm{E}\end{array}$ & 304 & $\begin{array}{l}\text { Depositional zone slack } \\
\text { water, deposition of finer sediment } \\
\text { particles. } \\
\text { Water clear, broad and deep, slow- } \\
\text { running, dense vegetation, muddy } \\
\text { substratum. }\end{array}$ & $\begin{array}{l}\text { Phragmites australis,Typha } \\
\text { capensis, Cyperus mar- } \\
\text { ginatus, Schoenoplectus } \\
\text { paludicola, Ludwigia } \\
\text { adscendens diffusa, Azolla } \\
\text { pinnata and Spirodela sp. } \\
\end{array}$ \\
\hline Site $4 \mathrm{~B}$ & $\begin{array}{l}\text { Letaba } \\
\text { district }\end{array}$ & $\begin{array}{l}\text { Selati River } \\
\text { west of } \\
\text { Phalaborwa. } \\
\text { Lowland zone. }\end{array}$ & $\begin{array}{l}23^{\circ} 58^{\prime} 48.0^{\prime \prime} \mathrm{S} \\
31^{\circ} 04^{\prime} 21.6^{\prime \prime} \mathrm{E},\end{array}$ & 357 & $\begin{array}{l}\text { Erosional zone. } \\
\text { Water from clear to cloudy, densely } \\
\text { overgrown with thatching reed, } \\
\text { muddy substratum. }\end{array}$ & $\begin{array}{l}\text { Phragmites mauri- } \\
\text { tianus, Cyperus mar- } \\
\text { ginatus and Veronica } \\
\text { anagallis-aquatica }\end{array}$ \\
\hline
\end{tabular}

of which Tarebia granifera, an exotic invader species and Melanoides tuberculata represented $96 \%$ and $4 \%$, respectively, of the specimens sampled. The Baetidae, Caenagrionidae, Caenidae, Chironomidae and Tubificidae were collected at all of the sampling sites (Table 3). The Corixidae, Daphnidae, Glossophoniidae and Simuliidae were collected at 6 of the sites, while the Naididae, Physidae and Thiaridae were collected at 5 , 4 and 3 of the sites, respectively. The total number of specimens collected per site ranged from 696 (Site 3A) to 11764 (Site 4A) (Table 3).

The total number of families, as well as the percentage occurrence of tolerant, moderately sensitive and highly sensitive families, are summarised in Table 4. From this it is evident that no more than $57.9 \%$ of the total number of families collected during the study were found at any one of the sampling sites. In total, 8 more families were collected in the low-flow than in the high-flow season. The monthly flow data from January 2010 to October 2011 (DWAF, 2011), spanning the period of investigation, are presented in Fig. 2. The number of families collected at Sites 1 and 2B during the high-flow season, respectively represented the highest and lowest percentage

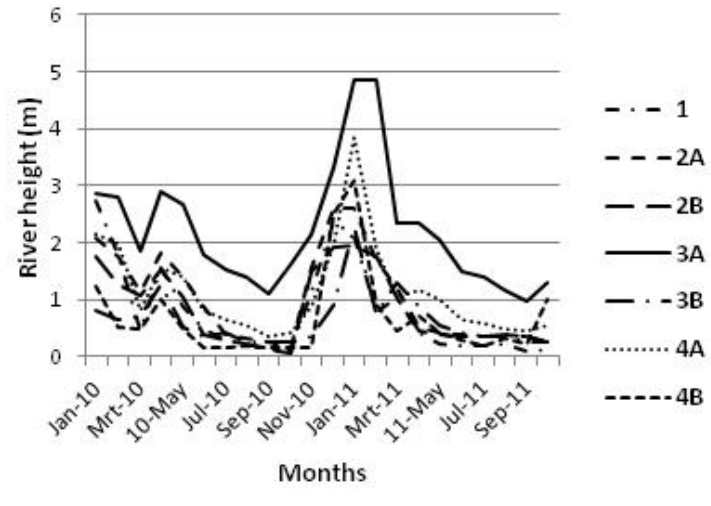

Figure 2

Monthly flow-data from January 2010 to October 2011(DWAF, 2011)

of the total number of families collected, while the number of families collected at Sites 4A and 2B during the low-flow season respectively represented the highest and lowest percentage of the total number of families collected across all the sites 
TABLE 2

Taxa listed according to the number of specimens collected as occurring in less or more than $1 \%$ of the total number of specimens found during the study.

\begin{tabular}{|c|c|}
\hline $\begin{array}{l}\text { Taxa \% occurrence } \\
<1 \%\end{array}$ & \begin{tabular}{|l|}
$\begin{array}{l}\text { Taxa \% occurrence } \\
<1 \%\end{array}$ \\
\end{tabular} \\
\hline Aeshnidae & Limnichidae \\
\hline Ancylidae & Lymnaeidae \\
\hline Argulidae & Mesoveliidae \\
\hline Athericidae & Mideopsidae \\
\hline Atyidae & Muscidae \\
\hline Belostomatidae & Naucoridae \\
\hline Blephariceridae & Nepidae \\
\hline Ceratopogonidae & Noteridae \\
\hline Chaoboridae & Notonectidae \\
\hline Chrysomelidae & Oligoneuriidae \\
\hline Corbiculidae & Paramelitidae \\
\hline Corduliidae & Paraphrynoveliidae \\
\hline Corydalidae & Planariidae \\
\hline Crambidae & Planorbidae \\
\hline Culicidae & Pleidae \\
\hline Curculionidae & Potamonautidae \\
\hline Cyprididae & Protojaniridae \\
\hline Diaptomidae & Protoneuridae \\
\hline Dipseudopsidae & Psephenidae \\
\hline Dixidae & Psychodidae \\
\hline Dolidopodidae & Saldidae \\
\hline Dryopidae & Salifidae \\
\hline Dytiscidae & Scirtidae \\
\hline Ecnomidae & Spercheidae \\
\hline Elmidae & Sphaeriidae \\
\hline Ephydridae & Sphaeriusidae \\
\hline Gerridae & Stenopsychidae \\
\hline Gomphidae & Stratiomyidae \\
\hline Gyrinidae & Streptocephalidae \\
\hline Haliplidae & Tabanidae \\
\hline Hebridae & Tipulidae \\
\hline Helicopsychidae & Thaumaleidae \\
\hline Heptageniidae & Tricorythidae \\
\hline Hydrachnellae & Veliidae \\
\hline Hydrachnidae & Taxa \% occurrence \\
\hline Hydraenidae & $>1 \%$ \\
\hline Hydridae & Baetidae \\
\hline Hydrochidae & Caenagrionidae \\
\hline Hydrometridae & Caenidae \\
\hline Hydroscaphidae & Chironomidae \\
\hline Hydrophilidae & Corixidae \\
\hline Hydropsychidae & Daphnidae \\
\hline Hydroptilidae & Glossiphoniidae \\
\hline Iridinidae & Naididae \\
\hline Isotomidae & Physidae \\
\hline Leptoceridae & Simuliidae \\
\hline Leptophlebiidae & Thiaridae \\
\hline Libellulidae & Tubificidae \\
\hline
\end{tabular}

throughout the study. With regard to the number of toleran families, it is clear that it ranged between 18 (Site 4A) and 39 (Site 1), and between 20 (Site 2B) and 42 (Site 4A) for the highand low-flow seasons, respectively, while the number of moderately sensitive families ranged between 5 (Site 2B) and 15 (Site 3B), and between 4 (Site 2B) and 15 (Site 3B) for the high and low-flow seasons respectively. The number of highly sensitive families ranged between 0 (Site 1) and 4 (Site 3B) and between 0 (Sites 1 and 4B) and 5 (Site 4A) for the high and low-flow seasons, respectively.

The biodiversity indices for the combined datasets of macroinvertebtrates collected in sediment and on plants is summarised in Table 5. The species richness varied considerably between the different sites and surveys (Table 5). The lowest species richness was observed for Site 4A (Survey 1) and the highest for Site 4A (Survey 4; Table 5). Except for Site 2B Survey 2, Site 2A Survey 3 and Site 4 A surveys $1-3$, all of the remaining sites displayed a Shannon Index value $\left(\mathrm{H}^{\prime}\right)$ that represents biodiversity of between 1.5 and 3.5. With regard to Pielou's evenness index $\left(J^{\prime}\right)$, values ranged between 0.08 (Site $4 \mathrm{~A}$ Survey 3 ) and 0.87 (Sites 1 Survey 1 and Site 3A Survey 1). For this index, values can vary between 1 and 0 , representing an even and uneven distribution of abundance, respectively. When an ecosystem is healthy, it is generally assumed that there will be consistent patterns of distribution evenness within a given community.

In the PCA-tri-plot, (Fig. 3), average temperature is associated with the top right quadrant. This indicates that average temperature is closely associated with Sites $4 \mathrm{~A}$ and $4 \mathrm{~B}$, as well as Prosobranchia and Lepidoptera. The river flow rate, temperature of the sampling site on day of collection and the river height are grouped in the bottom right quadrant of the PCAtri-plot. The river flow rate and the temperature of the sampling site on day of collection are strongly associated with Factor 1, whereas the river flow height is strongly associated with Factor 2 and sites on this axis within the bottom right quadrant of the PCA-tri-plot. Average rainfall and height above sea-level occur in the bottom left quadrant of the PCA-tri-plot, associating equally with Factor 1 and 2. The $\mathrm{pH}$ and EC grouped in the upper left quadrant and were associated with Sites 1, 2A, 2B and $4 \mathrm{~A}$. The $\mathrm{pH}$ associated with Factor 1 and EC with Factor 2. With regard to the orders, it is evident that $12,3,0$ and 9 orders grouped in the upper left, upper right, bottom right and bottom left quadrants respectively (Fig. 3).

The relative abundance calculated was used to plot the $\mathrm{K}$-dominance curves for each sampling incidence per site. In the K-dominance curves, curves representing sites impacted by pollution or other habitat disturbances are J-shaped. The K-dominance varied considerably between the different surveys at the various sampling sites. For Sites 1, 2A, 2B, $3 \mathrm{~A}$ and $3 \mathrm{~B}$ the first surveys indicated a more even spread of individuals per species. For Site $2 \mathrm{~B}$ there was a drastic change in the shape of the dominance curve during the second survey and for Sites 1, 2A, 2B, 3A and $3 \mathrm{~B}$ a drastic change during the third survey. Both Sites $4 \mathrm{~A}$ and $4 \mathrm{~B}$ showed J-shaped curves from onset (Fig. 4).

\section{DISCUSSION}

As mentioned in the introduction the general perception of the health of the Olifants River and its catchment, as reflected by several recent studies (De Lange et al., 2005; Chapman, 2006; Beumer, 2010), is that it varies from moderate to poor. This is possibly due to anthropogenic influences such as 
Table 3

The most abundant taxa and their numbers and percentage occurrence at each site

\begin{tabular}{|c|c|c|c|c|c|c|c|c|c|c|c|c|c|c|}
\hline & \multicolumn{2}{|c|}{1} & \multicolumn{2}{|c|}{$2 A$} & \multicolumn{2}{|c|}{$2 B$} & \multicolumn{2}{|c|}{$3 \mathrm{~A}$} & \multicolumn{2}{|c|}{ 3B } & \multicolumn{2}{|c|}{$4 \mathrm{~A}$} & \multicolumn{2}{|c|}{$4 \mathrm{~B}$} \\
\hline & $\mathrm{N}$ & $\%$ & $\mathrm{n}$ & $\%$ & $\mathrm{n}$ & $\%$ & $\mathrm{~N}$ & $\%$ & $\mathrm{n}$ & $\%$ & $\mathrm{~N}$ & $\%$ & $\mathrm{n}$ & $\%$ \\
\hline Baetidae & 1087 & $19.91 \%$ & 1529 & $30.19 \%$ & 514 & $7.27 \%$ & 194 & $27.87 \%$ & 124 & $11.34 \%$ & 199 & $1.69 \%$ & 129 & $3.86 \%$ \\
\hline Caenagrionidae & 122 & $2.23 \%$ & 34 & $0.67 \%$ & 17 & $0.24 \%$ & 10 & $1.44 \%$ & 81 & $7.41 \%$ & 38 & $0.32 \%$ & 63 & $1.88 \%$ \\
\hline Caenidae & 25 & $0.46 \%$ & 7 & $0.14 \%$ & 17 & $0.24 \%$ & 62 & $8.91 \%$ & 104 & $9.52 \%$ & 13 & $0.11 \%$ & 120 & $3.59 \%$ \\
\hline Chironomidae & 956 & $17.51 \%$ & 84 & $1.66 \%$ & 187 & $2.64 \%$ & 65 & $9.34 \%$ & 200 & $18.30 \%$ & 56 & $0.48 \%$ & 596 & $17.83 \%$ \\
\hline Corixidae & 1448 & $26.53 \%$ & 1535 & $30.31 \%$ & 75 & $1.06 \%$ & 4 & $0.57 \%$ & 11 & $1.01 \%$ & 0 & $0.00 \%$ & 2 & $0.06 \%$ \\
\hline Daphnidae & 224 & $4.10 \%$ & 611 & $12.07 \%$ & 23 & $0.33 \%$ & 26 & $3.74 \%$ & 27 & $2.47 \%$ & 600 & $5.10 \%$ & 0 & $0.00 \%$ \\
\hline Glossophoni & 205 & $3.76 \%$ & 7 & $0.14 \%$ & 190 & $2.69 \%$ & 2 & $0.29 \%$ & 3 & $0.27 \%$ & 6 & $0.05 \%$ & 0 & $0.00 \%$ \\
\hline Naididae & 32 & $0.59 \%$ & 4 & $0.08 \%$ & 87 & $1.23 \%$ & 0 & $0.00 \%$ & 0 & $0.00 \%$ & 11 & $0.09 \%$ & 700 & $20.94 \%$ \\
\hline Physidae & 3 & $0.05 \%$ & 471 & $9.30 \%$ & 2 & $0.03 \%$ & 0 & $0.00 \%$ & 0 & $0.00 \%$ & 225 & $1.91 \%$ & 0 & $0.00 \%$ \\
\hline Simuliidae & 2 & \begin{tabular}{|l|}
$0.04 \%$ \\
\end{tabular} & 6 & $0.12 \%$ & 284 & $4.02 \%$ & 7 & $1.01 \%$ & 11 & $1.01 \%$ & 0 & $0.00 \%$ & 183 & $5.47 \%$ \\
\hline Thiaridae & 0 & $0.00 \%$ & 0 & $0.00 \%$ & 0 & $0.00 \%$ & 0 & $0.00 \%$ & 1 & $0.09 \%$ & 9707 & $82.51 \%$ & 698 & $20.88 \%$ \\
\hline Tubificidae & 118 & $2.16 \%$ & 40 & $0.79 \%$ & 5194 & $73.43 \%$ & 13 & $1.87 \%$ & 99 & $9.06 \%$ & 172 & $1.46 \%$ & 30 & $0.90 \%$ \\
\hline Total per site & \multicolumn{2}{|c|}{5459} & \multicolumn{2}{|c|}{5064} & \multicolumn{2}{|c|}{7073} & \multicolumn{2}{|c|}{696} & \multicolumn{2}{|c|}{1093} & \multicolumn{2}{|c|}{11764} & \multicolumn{2}{|c|}{3343} \\
\hline
\end{tabular}

\begin{tabular}{|c|c|c|c|c|c|c|c|c|c|}
\hline & & $\begin{array}{r}\text { Total number } \\
\text { moderatel }\end{array}$ & $\begin{array}{l}\text { of families, a } \\
\text { y sensitive an }\end{array}$ & $\begin{array}{l}\text { well as the } \\
\text { highly sen }\end{array}$ & $\begin{array}{l}\text { le } 4 \\
\text { bers and } \\
\text { e familie }\end{array}$ & $\begin{array}{l}\text { rcentage oc } \\
\text { ollected at } \mathrm{e}\end{array}$ & $\begin{array}{l}\text { rence of } \\
\text { samplin }\end{array}$ & ant, & \\
\hline & $\begin{array}{l}\text { Sampling } \\
\text { site }\end{array}$ & \begin{tabular}{|c|}
$\begin{array}{c}\text { Total number } \\
\text { of families/ } \\
\text { sampling site }\end{array}$ \\
\end{tabular} & $\begin{array}{c}\% \text { of total } \\
\text { number } \\
\text { of families** }\end{array}$ & $\begin{array}{c}\text { Number of } \\
\text { tolerant } \\
\text { families }\end{array}$ & $* * * \%$ & $\begin{array}{c}\text { Moderately } \\
\text { sensitive } \\
\text { families } \\
\end{array}$ & $* * * \%$ & $\begin{array}{c}\text { Highly } \\
\text { sensitive } \\
\text { families }\end{array}$ & $* * * \%$ \\
\hline High- & 1 & 51 & $53.7 \%$ & 39 & $76.5 \%$ & 12 & $23.5 \%$ & 0 & $0.0 \%$ \\
\hline & $2 \mathrm{~A}$ & 39 & $41.1 \%$ & 27 & $69.2 \%$ & 9 & $23.1 \%$ & 1 & $2.6 \%$ \\
\hline & $2 B$ & 28 & $29.5 \%$ & 22 & $78.6 \%$ & 5 & $17.9 \%$ & 1 & $3.6 \%$ \\
\hline & $3 \mathrm{~A}$ & 31 & $32.6 \%$ & 22 & $71.0 \%$ & 7 & $22.6 \%$ & 2 & $6.5 \%$ \\
\hline & $3 \mathrm{~B}$ & 41 & $43.2 \%$ & 22 & $53.7 \%$ & 15 & $36.6 \%$ & 4 & $9.8 \%$ \\
\hline & $4 \mathrm{~A}$ & 29 & $30.5 \%$ & 18 & $62.1 \%$ & 8 & $27.6 \%$ & 3 & $10.3 \%$ \\
\hline & $4 B$ & 36 & $37.9 \%$ & 26 & $72.2 \%$ & 10 & $27.8 \%$ & 0 & $0.0 \%$ \\
\hline Low- & 1 & 41 & $43.2 \%$ & 31 & $75.6 \%$ & 10 & $24.4 \%$ & 0 & $0.0 \%$ \\
\hline flow & $2 \mathrm{~A}$ & 32 & $33.7 \%$ & 22 & $68.8 \%$ & 9 & $28.1 \%$ & 1 & $3.1 \%$ \\
\hline & $2 \mathrm{~B}$ & 25 & $26.3 \%$ & 20 & $80.0 \%$ & 4 & $16.0 \%$ & 1 & $4.0 \%$ \\
\hline & $3 \mathrm{~A}$ & 42 & $44.2 \%$ & 32 & $76.2 \%$ & 8 & $19.0 \%$ & 2 & $4.8 \%$ \\
\hline & $3 \mathrm{~B}$ & 53 & $55.8 \%$ & 36 & $67.9 \%$ & 15 & $28.3 \%$ & 2 & $3.8 \%$ \\
\hline & $4 \mathrm{~A}$ & 55 & $57.9 \%$ & 42 & $76.4 \%$ & 8 & $14.5 \%$ & 5 & $9.1 \%$ \\
\hline & $4 \mathrm{~B}$ & 44 & $46.3 \%$ & 33 & $75.0 \%$ & 11 & $25.0 \%$ & 0 & $0.0 \%$ \\
\hline
\end{tabular}

* High-flow: 65 families; Low-flow: 73 families

* Percentage of total number of families collected during the study: 95 families

*** Percentage of total number of families collected at sampling site

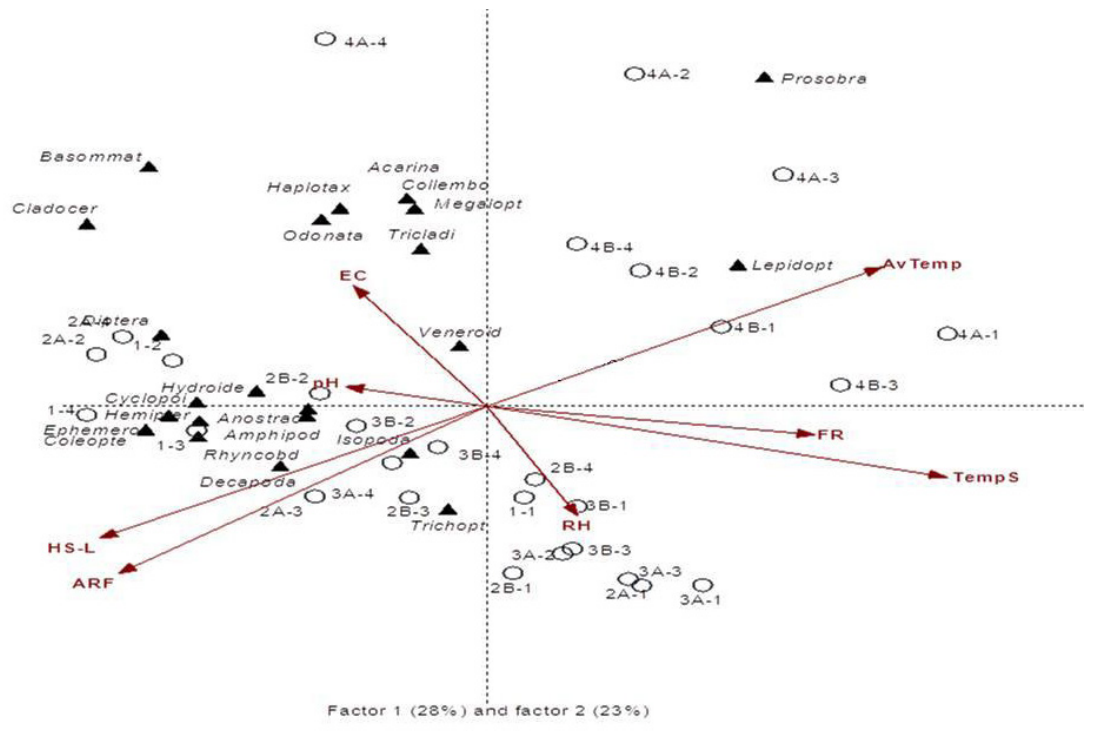

Figure 3

A PCA tri-plot of insect orders collected at the various sampling sites, as in Fig. 1, including environmental variables (GT: average temperature; FT: river flow rate; TM: temperature at sampling site on day of collection; $R H$ : river flow height; GR: average rainfall; HS: height above sea-level; $p H$; $E C$ : electrical conductivity). Sampling sites are indicated by squares while orders are indicated by diamond shapes and the environmental factors are denoted through vector arrows. 


\begin{tabular}{|c|c|c|c|c|c|}
\hline \multicolumn{6}{|c|}{$\begin{array}{c}\text { Table } 5 \\
\begin{array}{c}\text { A combination of biological indices calculated for the } \\
\text { different surveys at the various sampling sites. }\end{array}\end{array}$} \\
\hline Site & $\begin{array}{c}\text { Species } \\
\text { richness }\end{array}$ & $\mathrm{H}^{\prime}$ & $\mathrm{J}^{\prime}$ & $\begin{array}{c}\% \\
\text { Oligochaeta }\end{array}$ & $\begin{array}{c}\% \\
\text { Chironomidae }\end{array}$ \\
\hline $1-1$ & 19.00 & 2.56 & 0.87 & 5.39 & 9.80 \\
\hline $1-2$ & 31.00 & 1.68 & 0.49 & 8.58 & 59.41 \\
\hline $1-3$ & 45.00 & 1.87 & 0.49 & 0.00 & 3.47 \\
\hline $1-4$ & 34.00 & 2.42 & 0.69 & 2.22 & 7.10 \\
\hline $2 \mathrm{~A}-1$ & 17.00 & 2.30 & 0.81 & 0.00 & 0.79 \\
\hline $2 \mathrm{~A}-2$ & 26.00 & 1.90 & 0.58 & 0.97 & 2.71 \\
\hline $2 \mathrm{~A}-3$ & 34.00 & 1.40 & 0.40 & 0.00 & 0.67 \\
\hline $2 \mathrm{~A}-4$ & 30.00 & 1.91 & 0.56 & 1.63 & 1.44 \\
\hline $2 \mathrm{~B}-1$ & 19.00 & 1.59 & 0.54 & 0.00 & 0.95 \\
\hline $2 \mathrm{~B}-2$ & 21.00 & 0.41 & 0.14 & 92.65 & 1.61 \\
\hline $2 \mathrm{~B}-3$ & 20.00 & 2.28 & 0.76 & 27.20 & 15.95 \\
\hline $2 \mathrm{~B}-4$ & 20.00 & 1.90 & 0.63 & 64.44 & 3.33 \\
\hline $3 \mathrm{~A}-1$ & 15.00 & 2.35 & 0.87 & 0.00 & 6.25 \\
\hline $3 \mathrm{~A}-2$ & 23.00 & 2.38 & 0.76 & 0.47 & 8.84 \\
\hline $3 \mathrm{~A}-3$ & 24.00 & 2.41 & 0.76 & 0.00 & 0.00 \\
\hline $3 \mathrm{~A}-4$ & 38.00 & 2.74 & 0.75 & 3.77 & 13.84 \\
\hline $3 \mathrm{~B}-1$ & 27.00 & 2.78 & 0.84 & 4.62 & 1.54 \\
\hline $3 \mathrm{~B}-2$ & 33.00 & 2.71 & 0.77 & 5.60 & 24.33 \\
\hline $3 \mathrm{~B}-3$ & 31.00 & 2.29 & 0.67 & 0.52 & 4.19 \\
\hline $3 \mathrm{~B}-4$ & 42.00 & 2.64 & 0.71 & 19.66 & 25.64 \\
\hline $4 \mathrm{~A}-1$ & 11.00 & 0.36 & 0.15 & 1.23 & 0.00 \\
\hline $4 \mathrm{~A}-2$ & 27.00 & 0.45 & 0.14 & 2.28 & 0.11 \\
\hline $4 \mathrm{~A}-3$ & 32.00 & 0.28 & 0.08 & 0.57 & 0.07 \\
\hline $4 \mathrm{~A}-4$ & 49.00 & 2.17 & 0.56 & 1.93 & 1.93 \\
\hline $4 \mathrm{~B}-1$ & 31.00 & 2.11 & 0.62 & 1.48 & 0.49 \\
\hline $4 \mathrm{~B}-2$ & 28.00 & 2.05 & 0.62 & 0.74 & 14.58 \\
\hline $4 \mathrm{~B}-3$ & 20.00 & 1.70 & 0.57 & 0.32 & 0.00 \\
\hline 4B-4 & 31.00 & 1.64 & 0.48 & 46.46 & 28.33 \\
\hline
\end{tabular}

or the change in availability of nutrients due to the influx of rainwater (Cummins, 1972). Tubificids sometimes reach great numerical densities in pollution-altered running waters. These possibilities are supported by the presence of large quantities of filamentous algae and an exceptionally high water level during this specific survey. The fact that the Baetidae represented a relatively high percentage of the total number of individuals collected during this study and that it was recovered from all the sites investigated, seems to suggest that the general quality of the water could be relatively poor especially in the case of Sites 1 and 2A where the largest numbers of this family were recovered. According to Cummins (1972) the Baetidae often associates with erosional habitats. It is evident from our site description that 5 of the 7 sites are categorised in the erosional or intermediate zones. The intermediate zones have both erosional and depositional features.

The family Chironomidae which, according to literature (Thirion, 2006; Arimoro et al., 2011), also seems to have a preference for organically enriched habitats, as well as brackish water, was collected in largest numbers at Sites 1(intermediate zone) and 4B (erosional zone) which is in accordance with the habitat description of Cummins (1972). Furthermore, all families that were present in large numbers seem to have a preference for habitats with low water quality resulting from organic enrichment (Thirion, 2006), and the majority of these families were collected at all of the sampling sites. In contrast to this, several sensitive families, with a preference for good water quality (Thirion, 2006), were found only in small numbers at some of the sites.

The fact that 8 more families were collected during the lowflow season, while more highly sensitive families were found in the high-flow season (Table 4) is in accordance with reports in literature regarding the seasonal variability of macroinvertebrate assemblages elsewhere in South Africa (Dallas, 2004; Khoza et al., 2012). No more than $57.9 \%$ of the total number of families collected, were found at any one of the sampling sites during either the high or low-flow seasons. This may be due to either specific habitat preferences or to other external detrimental impacts on the river.

The fact that a high number of families was collected at flow modifications (impoundments), agriculture, mining an industrial demands. The current investigation was done to evaluate the river health from a macroinvertebrate diversity perspective.

As previously mentioned, T. granifera (Thiaridae) represented the highest numbers of all the organisms collected during the course of this study and was recovered mainly at two of the sampling sites $(4 \mathrm{~A}, 4 \mathrm{~B})$ both situated in warmer parts (Lowveld) of the study area (Table 3). This is in accordance with reports in literature that $T$. granifera shows a preference for warmer climates, although it can survive in water with temperatures ranging from 0 to $47^{\circ} \mathrm{C}$ (Miranda et al., 2002). An association between T. granifera and temperature was also indicated by the PCA. A plausible reason for the large numbers of Thiaridae collected at these two sites might be the habitat preferences of this family which includes slow current speed $(<0.1 \mathrm{~m} / \mathrm{s})$, low water quality, organic enrichment and the presence of aquatic vegetation (Thirion, 2006). The Tubificidae, which represented the second highest number of individuals, are generally present in habitats regarded as disturbed and are often used as indicators of such conditions (Cummins, 1972; Van Hoven and Day, 2002). With the exception of Site 2B, this family was recovered in small numbers. The fact that large numbers of this family were collected at only 1 site (2B) and during only 1 survey, could possibly be ascribed to sporadic impacts in the form of organic enrichment (Thirion, 2006) Health Programme as a natural and relatively undisturbed waterbody (Balance et al., 2001).This observation is supported by the fact that a relatively high number of highly sensitive families (Paramelitidae, Heptageniidae, Leptophlebiidae and Crambidae) was also recovered at this site. It is interesting to mention that all these families are associated with an erosional zone (Cummins, 1972) which is characteristic of Site 3B (Blyde River). It is well known that the Blyde River has a rejuvenating effect downstream from its confluence with the Olifants River (Balance et al., 2001; Raven, 2004) as reflected by the high number of sensitive families collected at Sites $3 \mathrm{~A}$ and $4 \mathrm{~A}$. Although a relatively high number of families was recovered from Site 1 , which is the site nearest to the origin, no sensitive families were collected here. This was probably due to organic enrichment caused by agricultural practices observed in the vicinity of this site. In accordance with the literature (Balance et al., 2001; Chapman, 2006; Environomics, 2009) which describes the Selati River as being in a poor to fair state, no sensitive families were found here.

The fact that Site $2 \mathrm{~B}$ showed the lowest mean species richness throughout the study was probably due to poor biotope diversity, as this site was characterised by bedrock and sparse vegetation. 

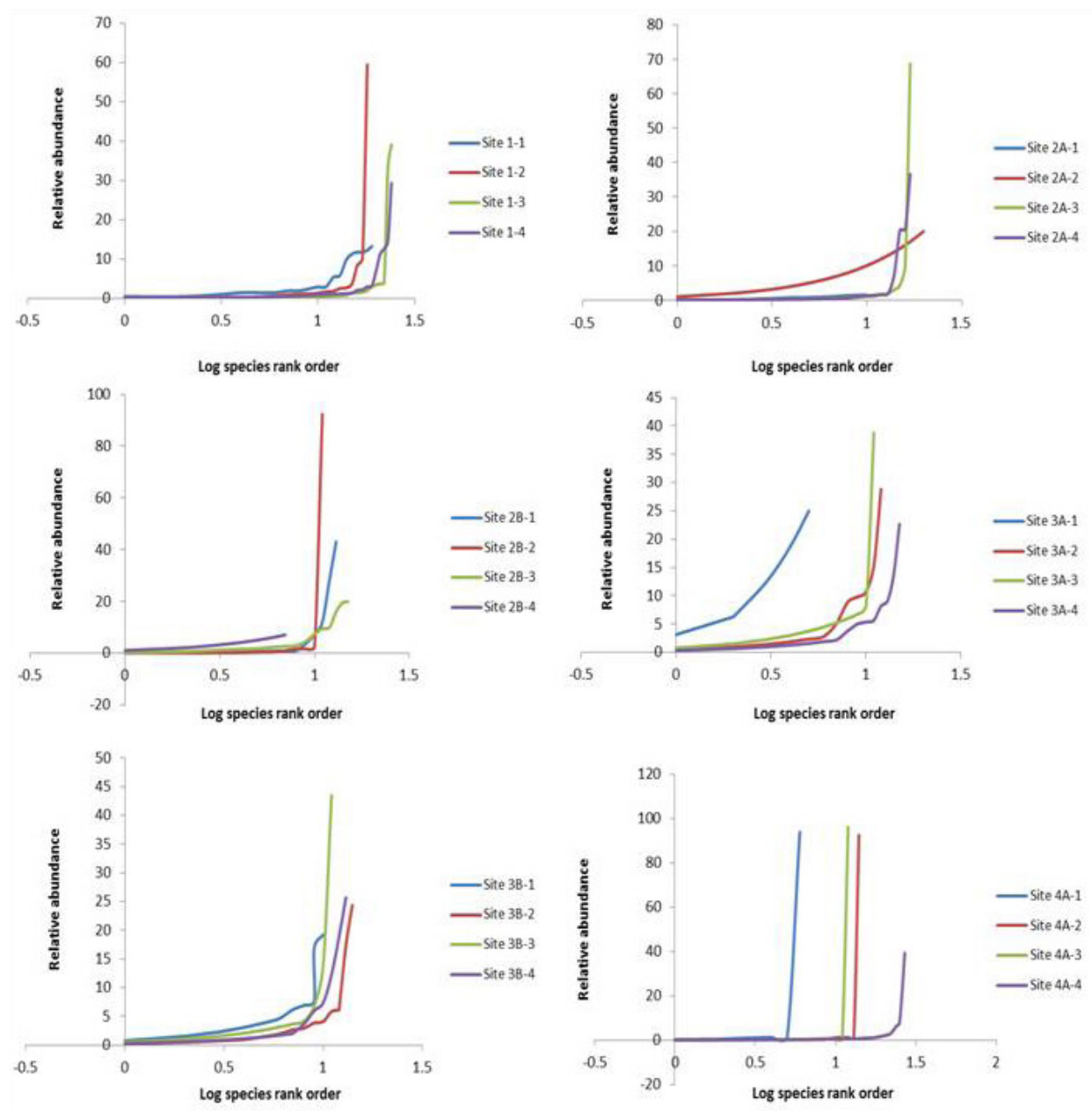

\section{K-Dominance curves of the relative abundance and log species rank order for each site for the different surveys}

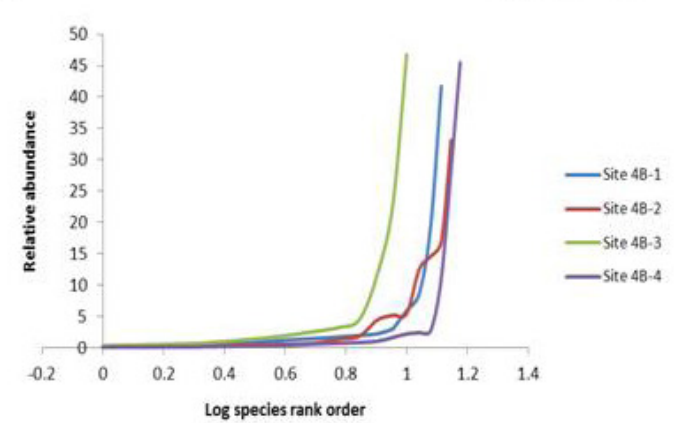

The relatively low values calculated for biodiversity $\left(\mathrm{H}^{\prime}\right)$ for Site 2B (Survey 2) and for the first 3 surveys of Site 4A, could be ascribed to the high abundance of the Tubificidae and the Thiaridae, respectively. Both of these families are known for their specific preference for organically enriched habitats (Thirion, 2006). The positive correlation of $\mathrm{H}^{\prime}$ and $\mathrm{J}^{\prime}$ with river altitude could be ascribed to an increase in biotope diversity while the negative correlation of $\%$ Oligochaeta and $\%$ Chironomidae with the flow-rate of the river (results of Spearman Rank Order Correlation not shown) could be caused by specific habitat preferences (Harrison, 2003; Thirion, 2006).

With regard to the PCA tri-plot (Fig. 3), the average temperature closely associated with Sites $4 \mathrm{~A}$ and $4 \mathrm{~B}$, as well as Prosobranchia, Lepidoptera and Araneae. According to Eady et al. (2013) variable stream temperatures are an important critical factor in maintaining aquatic invertebrate community patterns.

Although the minimum $\mathrm{pH}$ values were never lower than the minimum value of the $\mathrm{pH}$ range for African freshwater bodies (Holmes, 1996), the maximum $\mathrm{pH}$ values were often exceeded in this study (results not shown). According to the PCA analysis the orders Hydroidea, Cladocera, and Diptera were associated with $\mathrm{pH}$. The $\mathrm{pH}$ values recorded for Site $2 \mathrm{~A}$ were generally the highest with values ranging between 7.85 and 9.45 , while the values recorded at Site $3 \mathrm{~B}$ were generally the lowest (6.93-8.05). The lower $\mathrm{pH}$ at Site $3 \mathrm{~B}$ could reflect the association with the sandstone geology of the rejuvenation zone. The EC recorded at the various sites ranged between 110 and $1336 \mu \mathrm{S} / \mathrm{cm}$ (results not shown), which fell within the range reported for other freshwater bodies in South Africa (Schutte and Frank, 1964; De Kock and Van Eeden, 1969). The lowest and highest EC values were recorded at Sites 3B and $4 \mathrm{~B}$, respectively. Associations between $\mathrm{EC}$ and the orders Haplotaxina, Acarina, Collembola, Megaloptera, Tricladida, Odonata, Basommatophora and Cladocera were found (Fig. 3).

The drastic change in the shape of the K-dominance curves during the second survey at Sites 1 and $2 \mathrm{~B}$ was due to the high 
numbers of the Chironomidae and Tubificidae, respectively, while similar changes in the shape of the curves during the third survey at Sites 1, 2A, 2B, 3A and 3B were due to the high number of Corixidae at Site 1 and Baetidae at all of these sites. The phenomenon that Sites $4 \mathrm{~A}$ and $4 \mathrm{~B}$ showed J-shaped curves for all of the surveys can be ascribed to the presence of high numbers of the Thiaridae.

\section{CONCLUSION}

From this study it was evident that considerable variation occurred with regard to the families found between the various surveys and between each of the collection sites. These variations possibly resulted from a combination of environmental and physical conditions, which include the conditions of the habitats, habitat availability changing with flow, seasonal variation in macroinvertebrate communities (Khoza et al., 2012) and seasonal water quality impacts. Although the Tubificidae and Thiaridae sporadically showed exceptional numerical densities caused by pollution-altered conditions, the duration of these conditions could not be established during this investigation. While the level of organic enrichment encountered at some of these sites seemed to benefit those families known to be tolerant to, or to have a preference for, such conditions, the impact of these levels on the ecosystem were not so drastic that highly sensitive families were totally absent.

Although 7 of the 11 highly sensitive families previously recorded from the area were recovered during this study, the majority of these families were predominantly found at sites which were not obviously organically polluted. From these observations it is clear that, in accordance with literature, only some parts of the Olifants River should be regarded as being in a poor state of health. It is recommended that future research should focus on more frequent surveys of additional sites, over a longer period, in order to monitor the possible deterioration or improvement of the ecosystem health of the Olifants River.

\section{ACKNOWLEDGEMENTS}

We are indebted to the Unit for Environmental Sciences and Management, North-West University, Potchefstroom, South Africa for financial support and infrastructure.

\section{REFERENCES}

APPLETON CC (2002a) Platyhelminthes. In: Day JA and De Moor IJ (eds) Guides to the Freshwater Invertebrates of Southern Africa, Non-Arthropods. WRC Report No. TT 167/02. Water Research Commission, Pretoria. 88-110.

APPLETON CC (2002b) Mollusca. In: Day JA, and De Moor IJ (eds.) Guides to the Freshwater Invertebrates of Southern Africa, Araneae, Water Mites and Mollusca. WRC Report No. TT 182/02. Water Research Commission, Pretoria. 42-125.

ARIMORO FO, IKOMI RB, AJUZIEOGU IO and NWADUKWE FO (2011) Temporal and spatial variability in macroinvertebrate community structure in relation to environmental variables in Ajijiguan Creek, Niger Delta, Nigeria. Afr. J. Aquat. Sci. 36 57-66.

BALLANCE A, HILL L, ROUX D, SILBERBAUER M and STRYDOM W (2001) State of the Rivers Report: Crocodile, Sabie- Sand and Olifants River Systems. Resource Quality Services, DWAF, Pretoria.

BARBER-JAMES HM and LUGO-ORTIZ CR (2003) Ephemeroptera. In: De Moor IJ, Day JA and De Moor FC (eds.) Guides to the Freshwater Invertebrates of Southern Africa, Ephemeroptera, Odonata and Plecoptera. WRC Report No. TT 207/03. Water Research Commission, Pretoria. 16-142.
BATCHELOR GR (1992) From dammed to damned. Fauna and Flora $4822-29$.

BEGON M, HARPER JL and TOWNSEND CR (1996) Ecology (3rd edn.). Blackwell Science Ltd, London.

BEUMER J (2010) Development of a reconciliation strategy for the Olifants River Water Supply System. Inception Report WP 10197. Department of Water Affairs, Pretoria. 1-127.

BISTRÖM O (2007) Dytiscidae In: Stals R and De Moor IJ (eds.) Guides to the Freshwater Invertebrates of Southern Africa, Coleoptera. WRC Report No. TT 320/07. Water Research Commission, Pretoria. 69-84.

CHAPMAN A (2006) Hydrology and land use in the Ga-Selati catchment. CSIR, Pretoria, South Africa and International Institute for Environment and Development, London, UK.

COETZEE M (2003) Culicidae. In: Day JA, Harrison AD and De Moor IJ (eds.) Guides to the Freshwater Invertebrates of Southern Africa, Diptera. WRC Report No. TT 201/02. Water Research Commission, Pretoria. 57-74.

CSIR (2012) Risk Assessment of Pollution in Surface Waters of the Upper Olifants River System: Implications for Aquatic Ecosystem Health and the Health of Human Users of Water. Upper Olifants River Study: Phase 2 Draft Report. CSIR, Pretoria.

CUMMINS KW (1972) What is a river? - Zoological description. In: Oglesby RT, Carlson CA and McCAN JA (eds.) River Ecology and Man. Academic Press, New York. 456 pp.

DALLAS HF (2004) Seasonal variability of macroinvertebrate assemblages in two regions of South Africa: implications for aquatic bioassessment. Afr. J. Aquat. Sci. 29 173-184.

DALLAS H F and DAY JA (1993) The effect of water quality variables on riverine ecosystems: A review. WRC Report No. TT 61/93. Water Research Commission, Pretoria.

DAVIES B and DAY J (1998) Vanishing Waters. University of Cape Town Press, Cape Town. 487 pp.

DE KOCK KN and VAN EEDEN JA (1969) Die verspreiding en habitatseleksie van die Mollusca in die Mooirivier, Transvaal. Wetenskaplike Bydraes van die PU vir CHO, Reeks B: Natuurwetenskappe 8 1-119.

DE KOCK KN and WOLMARANS CT (1998) A re-evaluation of the occurrence of freshwater molluscs in the Kruger National Park. Koedoe 41 1-8.

DE KOCK KN, WOLMARANS CT and DU PREEZ LH, (2002) Freshwater mollusc diversity in the Kruger National Park: a comparison between a period of prolonged drought and a period of exceptionally high rainfall. Koedoe 45 1-11.

DE LANGE M, MERREY DJ, LEVITE H and SVENDSEN M (2005) Water Resources Planning and Management in the Olifants Basin of South Africa: Past, Present and Future. In: Svendsen M (ed.) Irrigation and River Basin Management. CAB International, Wallingford. 145-168.

DE MEILLON B and WIRTH WW (2003) Ceratopogonidae. In: Day JA, Harrison AD and De Moor IJ (eds.) Guides to the Freshwater Invertebrates of Southern Africa, Diptera. WRC Report No. TT 201/02. Water Research Commission, Pretoria. 50-56.

DE MOOR FC (2003) Simuliidae. In: Day JA, Harrison AD and De Moor IJ (eds.) Guides to the Freshwater Invertebrates of Southern Africa, Diptera. WRC Report No. TT 201/02. Water Research Commission, Pretoria. 75-109.

DE MOOR FC and SCOTT KMF (2003) Trichoptera. In: De Moor IJ, Day JA and De Moor FC (eds.) Guides to the Freshwater Invertebrates of Southern Africa, Hemiptera, Megaloptera, Neuroptera, Trichoptera and Lepidoptera. WRC Report No. TT 214/03. Water Research Commission, Pretoria. 84-169.

DWAF (DEPARTMENT OF WATER AFFAIRS AND FORESTRY, SOUTH AFRICA) (2011) Hydrological Services: Surface Water (Data, Dams, Floods and Flows). URL: http://www.dwaf.gov.za/ Hydrology (Accessed 2 April 2012).

DE VILLIERS S and MKWELO ST (2009) Has monitoring failed the Olifants River, Mpumalanga? Water SA 35 671-676.

DICKENS CWS and GRAHAM PM (2002) The South African Scoring System (SASS) Version 5 Rapid Bioassessment Method for Rivers. Afr. J. Aquat. Sci. 27 1-10. 
DIPPENAAR-SCHOEMAN AS (2002) Araneae. In: Day JA and De Moor IJ (eds.) Guides to the Freshwater Invertebrates of Southern Africa, Araneae, Water Mites and Mollusca. WRC Report No. TT 182/02. Water Research Commission, Pretoria. 5-22.

EADY BR, RIVERS-MOORE NA and HILL TR (2013) Relationship between water temperature predictability and aquatic macroinvertebrate assemblages in two South African streams. Afr. J. Aquat. Sci. 38 1-10.

ENDRÖDY-YOUNGA S (2007a) Spercheidae. In: Stals R and De Moor IJ (eds.) Guides to the Freshwater Invertebrates of Southern Africa, Coleoptera. WRC Report No. TT 320/07. Water Research Commission, Pretoria. 97-99.

ENDRÖDY-YOUNGA S (2007b) Limnichidae. In: Stals R and De Moor IJ (eds.) Guides to the Freshwater Invertebrates of Southern Africa, Coleoptera. WRC Report No. TT 320/07. Water Research Commission, Pretoria. 159-161

ENDRÖDY-YOUNGA S and STALS R (2007a) Haliplidae. In: Stals $\mathrm{R}$ and De Moor IJ (eds.) Guides to the Freshwater Invertebrates of Southern Africa, Coleoptera. WRC Report No. TT 320/07. Water Research Commission, Pretoria. 59-62.

ENDRÖDY-YOUNGA S and STALS R (2007b) Noteridae. In: Stals $\mathrm{R}$ and De Moor IJ (eds.) Guides to the Freshwater Invertebrates of Southern Africa, Coleoptera. WRC Report No. TT 320/07. Water Research Commission, Pretoria. 63-68.

ENDRÖDY-YOUNGA S and STALS R (2007c) Hydrochidae. In: Stals $\mathrm{R}$ and De Moor IJ (eds.) Guides to the Freshwater Invertebrates of Southern Africa, Coleoptera. WRC Report No. TT 320/07. Water Research Commission, Pretoria. 93-95.

ENDRÖDY-YOUNGA S and STALS R (2007d) Scirtidae. In: Stals R and De Moor IJ (eds.) Guides to the Freshwater Invertebrates of Southern Africa, Coleoptera. WRC Report No. TT 320/07. Water Research Commission, Pretoria. 133-137.

ENGELBRECHT J (1992) Acid rain and toxic water. Fauna and Flora 48 15-21.

ENVIRONOMICS: ENVIRONMENTAL CONSULTANTS (2009) Environmental Management Framework for the Olifants and Letaba River Catchment Areas: Draft Report on the Status Quo, Opportunities, Constraints and the Desired State. URL: http:// www.metrogis.co.za/docs/Draft Status Quo Report 3.pdf (Accessed 6 June 2012).

GERBER A, CILLIERS CJ, VAN GINKEL C and GLEN R (2004) Easy Identification of Aquatic Plants. Department of Water Affairs and Forestry, Pretoria. 73 pp.

GERBER A and GABRIEL MJM (2002a) Aquatic Invertebrates of South African Rivers, Field Guide ( $1^{\text {st }}$ edn.). Institute for Water Quality Studies, Department of Water Affairs and Forestry (DWAF), Pretoria. $150 \mathrm{pp}$.

GERBER A and GABRIEL MJM (2002b) Aquatic Invertebrates of South African Rivers, Illustrations, Version 2. Institute for Water Quality Studies, Department of Water Affairs and Forestry (DWAF), Pretoria. $12 \mathrm{pp}$.

GRIFFITHS CL and STEWART BA (2001) Amphipoda. In: Day JA, Stewart BA, De Moor IJ and Louw AE (eds.) Guides to the Freshwater Invertebrates of Southern Africa, Crustacea III. WRC Report No. TT 141/01. Water Research Commission, Pretoria. 28-49.

GROBBELAAR E (2007) Chrysomelidae: Donaciinae. In: Stals R and De Moor IJ (eds.) Guides to the Freshwater Invertebrates of Southern Africa, Coleoptera. WRC Report No. TT 320/07. Water Research Commission, Pretoria. 177-182.

HAMER M (1999) Anostraca. In: Day JA, Stewart BA, De Moor IJ and Louw AE (eds.) Guides to the Freshwater Invertebrates of Southern Africa, Crustacea 1. WRC Report No. TT 121/00. Water Research Commission, Pretoria. 14-58.

HARRISON AD (2003) Chironomidae. In: Day JA, Harrison AD and De Moor IJ (eds.) Guides to the Freshwater Invertebrates of Southern Africa, Diptera. WRC Report No. TT 201/02. Water Research Commission, Pretoria. 110-158.

HARRISON AD, PRINS A and DAY JA (2003a) Lesser-known Nematocera. In: Day JA, Harrison AD and De Moor IJ (eds.) Guides to the Freshwater Invertebrates of Southern Africa, Diptera. WRC
Report No. TT 201/02. Water Research Commission, Pretoria. $26-49$.

HARRISON AD, PRINS A and DAY JA (2003b) Brachycera. In: Day JA, Harrison AD and De Moor IJ (eds.) Guides to the Freshwater Invertebrates of Southern Africa, Diptera. WRC Report No. TT 201/02. Water Research Commission, Pretoria. 159-176.

HART R, STEWART BA and BICKERTON I (2001) Decapoda. In: Day JA, Stewart BA, De Moor IJ and Louw AE (eds.) Guides to the Freshwater Invertebrates of Southern Africa, Crustacea 3. WRC Report No. TT 141/01. Water Research Commission, Pretoria. 87-123.

HEATH R, COLEMAN T and ENGELBRECHT J (2010) Water quality overview and literature review of the ecology of the Olifants River. WRC Report No. TT 452/10. Water Research Commission, Pretoria.

HENNING SF (2003) Lepidoptera. In: De Moor IJ, Day JA and De Moor FC (eds.) Guides to the Freshwater Invertebrates of Southern Africa, Hemiptera, Megaloptera, Neuroptera, Trichoptera and Lepidoptera. WRC Report No. TT 214/03. Water Research Commission, Pretoria. 182-188.

HOLMES S (ed.) (1996) South African Water Quality Guidelines. Volume 7: Aquatic Ecosystems. Department of Water Affairs and Forestry (DWAF). Government Printer, Pretoria. 145 pp.

JANSEN VAN RENSBURG CA and DAY JA (2002) Water Mites. In: Day JA, and De Moor IJ (eds.) Guides to the Freshwater Invertebrates of Southern Africa, Araneae, Water Mites and Mollusca. WRC Report No. TT 182/02. Water Research Commission, Pretoria. 23-41

KENSLEY B (2001) Isopoda. In: Day JA, Stewart BA, De Moor IJ and Louw AE (eds.) Guides to the Freshwater Invertebrates of Southern Africa, Crustacea 3. WRC Report No. TT 141/01. Water Research Commission, Pretoria. 50-74.

KHOZA ZCC, POTGIETER MJ and VLOK W (2012) A preliminary survey of biotic composition of the Olifantspruit catchment, South Africa. Afr. J. Aquat. Sci. 37 201-208

MALAN HL and DAY JA (2003) Linking discharge, water quality and potential effects on aquatic biota, within the reserve determination process Water SA 29 297-304.

MALHERBE W, WEPENER V and VAN VUREN JHJ (2010) Anthropogenic spatial and temporal changes in the aquatic macro invertebrate assemblages of the lower Mvoti River, KwaZulu-Natal, South Africa. Afr. J. Aquat. Sci. 35 13-20.

MANSELL MW (2003) Megaloptera. In: De Moor IJ, Day JA and De Moor FC (eds.) Guides to the Freshwater Invertebrates of Southern Africa, Hemiptera, Megaloptera, Neuroptera, Trichoptera and Lepidoptera. WRC Report No. TT 214/03. Water Research Commission, Pretoria. 72-78.

MARTENS K (2001) Ostracoda. In: Day JA, De Moor IJ, Stewart BA and Louw AE (eds.) Guides to the Freshwater Invertebrates of Southern Africa, Crustacea 1. WRC Report No. TT 148/01. Water Research Commission, Pretoria. 9 -77.

MASESE FO, MUCHIRI M and RABURU PO (2009) Macroinvertebrate assemblages as biological indicators of water quality in the Moiben River, Kenya. Afr. J. Aquat. Sci. 34 15-26.

MIRANDA NAF, PERISSINOTTO R and APPLETON CC (2002) Salinity and temperature tolerance of the invasive freshwater gastropod Tarebia granifera. S. Afr. J. Sci. 106 (3/4) Art. \#156, 7 pp DOI: $10.4102 /$ sajs.v106i3/4.156.

NELSON HG (2007a) Elmidae. In: Stals R and De Moor IJ (eds.) Guides to the Freshwater Invertebrates of Southern Africa, Coleoptera. WRC Report No. TT 320/07. Water Research Commission, Pretoria. 139-152.

NELSON HG (2007b) Dryopidae. In: Stals R and De Moor IJ (eds.) Guides to the Freshwater Invertebrates of Southern Africa, Coleoptera. WRC Report No. TT 320/07. Water Research Commission, Pretoria. 153-157.

OBERHOLSTER PJ, BOTHA AM and CLOETE E (2005) Using a battery of bioassays, benthic phytoplankton and the AUSRIVAS method to monitor long-term coal tar contaminated sediment in the Cache la Poudre River, Colorado. Water Res. 39 4913-4924.

O'KEEFFE J and LE QUESNE T (2009) Keeping Rivers Alive: A Primer on Environmental Flows and Their Assessment. WWF Water

http://dx.doi.org/10.4314/wsa.v40i2.6

Available on website http://www.wrc.org.za

ISSN 0378-4738 (Print) = Water SA Vol. 40 No. 2 April 2014

ISSN 1816-7950 (On-line) = Water SA Vol. 40 No. 2 April 2014 
Security Series 2. World Wildlife Foundation, Surrey.

OOSTHUIZEN JH and SIDDAL ME (2002) Hirudinea. In: Day JA and De Moor IJ (eds.) Guides to the Freshwater Invertebrates of Southern Africa, Non-Arthropods. WRC Report No. TT 167/02. Water Research Commission, Pretoria. 237-263.

PERKINS PD (2007) Hydraenidae. In: Stals R and De Moor IJ (eds.) Guides to the Freshwater Invertebrates of Southern Africa, Coleoptera. WRC Report No. TT 320/07. Water Research Commission, Pretoria. 117-132.

PHIRI C, CHAKONA A and DAY JA (2012) Macroinvertebrates associated with two submerged macrophytes, Lagarosiphon ilicifolius and Vallisneria aethiopica, in the Sanyati Basin, Lake Kariba, Zimbabwe: effect of plant morphological complexity. Afr. J. Aquat. Sci. 37 277-288.

RASHLEIGH B, HARDWICK D and ROUX D (2009) Fish assemblage patterns as a tool to aid conservation in the Olifants River (East), South Africa. Water SA 35 517-514.

RAVEN BW (2004) Water affairs in the Lower Blyde River: The role of DWAF in local water management. IMWI Working Paper. IMWI, Wageningen.

RAYNER NA (2001) Copepods. In: Day JA, De Moor IJ, Stewart BA and Louw AE (eds.) Guides to the Freshwater Invertebrates of Southern Africa, Crustacea 1. WRC Report No. TT 148/01. Water Research Commission, Pretoria. 78-123.

RAYNER NA, APPLETON CC and MILLARD NAH (2002) Cnidaria. In: Day JA and De Moor IJ (eds.) Guides to the Freshwater Invertebrates of Southern Africa, Non-Arthropods. WRC Report No. TT 167/02. Water Research Commission, Pretoria. 74-87.

REAVELL PA (2003) Hemiptera. In: De Moor IJ, Day JA and De Moor FC (eds.) Guides to the Freshwater Invertebrates of Southern Africa, Hemiptera, Megaloptera, Neuroptera, Trichoptera and Lepidoptera. WRC Report No. TT 214/03. Water Research Commission, Pretoria. 16-71.

SAMWAYS MJ and WILMOT BC (2003) Odonata. In: De Moor IJ, Day JA and De Moor FC (eds.) Guides to the Freshwater Invertebrates of Southern Africa, Ephemeroptera, Odonata and Plecoptera. WRC Report No. TT 207/03. Water Research Commission, Pretoria. $160-200$.

SCHUTTE CHJ and FRANK GH (1964) Observations on the distribution of freshwater molluscs and chemistry of the natural waters in the South-eastern Transvaal and adjacent Northern Swaziland. Bull. World Health Org. 30 389-400.
SEAMAN MT, KOK DJ and WATSON M (1999) Cladocera. In: Day JA, Stewart BA, De Moor IJ and Louw AE (eds.) Guides to the Freshwater Invertebrates of Southern Africa, Crustacea 1. WRC Report No. TT 121/00. Water Research Commission, Pretoria. 81-110.

SHEPARD WD and LEE C-F (2007) Psephenidae. In: Stals R and De Moor IJ (eds.) Guides to the Freshwater Invertebrates of Southern Africa, Coleoptera. WRC Report No. TT 320/07. Water Research Commission, Pretoria. 167-172.

STALS R (2007a) Gyrinidae. In: Stals R and De Moor IJ (eds.) Guides to the Freshwater Invertebrates of Southern Africa, Coleoptera. WRC Report No. TT 320/07. Water Research Commission, Pretoria. 53-58.

STALS R (2007b) Curculionidae. In: Stals R and De Moor IJ (eds.) Guides to the Freshwater Invertebrates of Southern Africa, Coleoptera. WRC Report No. TT 320/07. Water Research Commission, Pretoria. 183-191.

STALS R and ENDRÖDY-YOUNGA S (2007) Hydrophilidae: Hydrophilinae. In: Stals R and De Moor IJ (eds.) Guides to the Freshwater Invertebrates of Southern Africa, Coleoptera. WRC Report No. TT 320/07. Water Research Commission, Pretoria. 101-112.

THIRION C (2006) River ecoclassification manual for ecostatus determination (Version 2). Module E: Macroinvertebrate Response Assessment Index (MIRAI). Department of Water Affairs and Forestry, Resource Quality Services, Pretoria.

TÜRKMEN G and KAZANCI N (2010) Applications of various biodiversity indices to benthic macroinvertebrate assemblages in streams of a national park in Turkey. Rev. Hydrobiol. 32 111-125.

VAN AS J and VAN AS LL (2001) Branchiura. In: Day JA, De Moor IJ, Stewart BA and Louw AE (eds.) Guides to the Freshwater Invertebrates of Southern Africa, Crustacea 2. WRC Report No. TT 148/01. Water Research Commission, Pretoria. 124-159.

VAN HOVEN W and DAY JA (2002) Oligochaeta. In: Day JA and De Moor IJ (eds.) Guides to the Freshwater Invertebrates of Southern Africa, Non-Arthropods. WRC Report No. TT 167/02. Water Research Commission, Pretoria. 203-236.

VAN VUUREN L (2009) Experts unite to save abused river from extinction. The Water Wheel 8 (Jan/Feb) 14-17.

WOLMARANS CT and DE KOCK KN (2006) The current status of freshwater molluscs in the Kruger National Park. Koedoe 49 39-44. 